\author{
Р. Досымбекова ${ }^{1}$, М. Дильманова ${ }^{2}$, А. Қойбақова ${ }^{3}$ \\ 1,3 Әл-Фараби атындывы Қазақ ұлттық университеті , \\ ${ }^{2}$ Абылай хан атындавы Қазақ хальқаралық құатынастар және әлем тілдері университеті, \\ Алматыл, Қазақсттан
}

ҰЛТТЫҚ КОЛОРИТ ЖӘНЕ РЕАЛИЯ СӨЗДЕРДІ АУДАРУДАҒЫ ҚИЫНДЫҚТАР

(Chunjie (Қытайдың жаңа жылы)мерекесіне қатысты реалиялар)

Аң̧датпа

Мақаладабір ұлттың, халықтың өзіне ғана тән тұмыстық, рухани, материалдық, тарихиқоғамдық құбылыстар мен заттардың тура мағынасын беретін реалия сөздерді аударудағы әдістер мен қиындықтар туралы баяндалады. Сонымен қатар аудармашылар және лингвистердің реалия сөздерді бір тілден екінші тілге аударудағы әдіс-тәсілдері, ой-тұжырымдары да айтылады. Қытай тіліндегі жаңа жыл мерекесіне қатысты реалияларды қарастырып, негізгі мәтін шеңберінде неғұрлым дұрыс және тиімді аудару нұсқасы жайлы баяндалды.

Түйін сөздер: реалия, ұлттық нақыш, транкрипция, калька, мәдениет

\author{
R. Dossymbekova ${ }^{1}$, M. Dilmanova ${ }^{2}$, A. Koybakova $^{3}$ \\ ${ }^{1,3}$ Al-Farabi Kazakh National University, \\ ${ }^{2}$ Kazakh Ablai khan University of International Relations and World Languages, \\ Almaty, Kazakhstan
}

\title{
NATIONAL CHARACTER AND DIFFICULTIES IN THE TRANSLATION OF THE WORD REALITY
}

This article reveals the concept of methods and difficulties in translating the words of reality, which give a direct meaning to vague, spiritual, material, historical and social phenomena and objects inherent in one nation and people. There are also ways in which translators and linguists can translate reality words from one language to another. There is also described the reality of the New Year celebration in Chinese and how to translate the most appropriate and effective translation into the main text.

Key words: reality, national character, transcription, tracing, culture

$$
\begin{gathered}
\text { Р. Досымбекова }{ }^{1}, \text { М. Дильманова }{ }^{2}, \text { А. Қойбакова }{ }^{3} \\
{ }^{2} \text { Казахский университет международных отношений и мировых языков имени Абылай хана, } \\
\text { Алматы, Казахстан }
\end{gathered}
$$

\section{НАЦИОНАЛЬНЫЙ КОЛОРИТ И ТРУДНОСТИ В ПЕРЕВОДЕ СЛОВРЕАЛИЙ}

\section{Аннотаичя}

В данной статье рассматривается понятие о методах и трудностях в переводе слов реалий, дающих прямое значение бытовым, духовным, материальным, историко-общественным явлениям и предметам, присущих одной нации, народу. Кроме того, речь идет о методах и подходах переводчиков и лингвистов, способах перевода слов реалий с одного языка на другой. Рассматривая реалии, касающиеся китайского нового года, в рамках основного текста речь шла о более правильном и эффективном варианте перевода.

Ключевые слова: реалия, национальный колорит, транкрипция, калька, культура

Кіріспе.Аударма теориясында әлі де өзекті, өткір талқыланып келе жатқан мәселе- ұлттық колорит, сөйлеу ерекшеліктері, реалиялар мен символдар. Реалия сөздер белгілі бір тұрғыда 
терминдермен және көнерген сөздермен ұқсас, сондықтан да олардың айырмашылығы мен ұқсастықтарын ажырата білгеніміз жөн. Реалия сөздер бір ұлттың ешқандай да ұлтқа ұқсамайтын өзіндік ерекшелігін бейнелейтін сөздер. "Реалия" латын сөзі, зат, нәрсе деген ұғымды білдіреді. Біздің қарастырып отырғанымыз ол белгілі бір ұлттың, халықтың өзіне ғана тән тұмыстық, рухани-мәдени, материалдық, тарихи-қоғамдық құбылыстар мен заттардың тура мағынасындағы номинативтік ұғымда қолданылады. Реалия бұл ұлттық нақышпен байланысты сөздер болғандықтан олардың мағыналық құрылымында ұлттық-мәдени компоненттер болады.Тіл мен мәдениеттің өзара қарым-қатынасының әсерінен лингвистикалық аспектілері зерттеліп, негізгі міндеттердің ауқымы бір мәдениетте болған және басқа тілде болмаған құбылыстарды зерттеуден тұрды, біз оларды лингвомәдени реалия деп атап көрсетеміз. Аудармашылар, лингвистердің “реалия" түсінігін аударма және тіл біліміндегі қолданыс аясы нақтыланған. Реалия сөздер 50жылдардың басында этникалық топтардың арасындағы қолданысы және оның ұлттық ерекшеліктерінің элементтерінің сақталуы туралы айтылған еді.

Әртүрлі мәдениеттегі халықтардың бірін-бірі жақынырақ тануының бір тетігі - аударма. Аударма үрдісінде аудармашыға үлкен қиындық тудыратыны - аударылатынтілде баламасы жоқ сөздер мен ұғымдар, яғни сөздің бойында болатын этноконнотативті ерекшеліктермен байланысты түсініктер. Мұндай сөздердің сипатын ашуға қолданылатын терминге қатысты А.В.Федоров пікір білдіріп, реалия басқа халықтың тұрмысы мен түсінігінде жоқ сөздер деп анықтайды [1,c.283]. Бұл түсінік бойынша реалия баламасыз дегенге саяды. Яғни баламасыз дегеніміз басқа тілдің лексикалық қорында толық немесе жартылай сәйкес келетін баламасы жоқ лексикалық бірліктер болып табылады. Осы тұста реалия ретінде қаралатын сөздер қандай өлшем бойынша анықталу қажет деген мәселе туындайды. Бұл орайда бінеше ғалымдар А.С.Ермагамбетова, Ж.А.Жакупов, С.И.Флорин, Г.Д.Томахин және т.б.зерттеушілер бір лингвомәдени қауымдастық өкілдерінің өмір сүру салтына, мәдениетіне және тұрмысына қатысты сөздерді реалия ретінде қарастырады.

Әдістеме. ХХ ғасырдың 60-жылдары С.Влахов пен С.Флориннің авторлығымен жарық көрген "Реалия" атты мақалада, кейінірек монографиядареалия сөзіне толық сипаттама беріліп, олардың жіктелуі мен реалия сөздерді аударудың әдіс-тәсілдері қарастырылған.

Тілдік кеңістікте реалиялар жалпы сөздер болып табылады және кеңінен қолданылады. Шет тіліндегі мәтіннің мұндай тілдік бірліктері дәл немесе сәйкес келетін сөздері (эквиваленттер) қолданады, сондықтан “ерекше көзқарасты талап ете отырып, жалпы негіздерге сүйену” арқылы аударма жасалады

[2, с.79]. Әр жолы, түпнұсқа мәтіндегі реалиямен тікелей аударғанда, аудармашы “бастапқы мәтіннің ұлттық және тарихи колоритін басқа тілге көшіру тәсілін іздеуге мәжбүр” болады [3, c.174].

Қытайдың ұлттық өзіндік болмысын аудару қиындығы туралы мәселені зерттеу өзектімәселелердің бірі. Қытай тіл-әдебиетіндегі, лингвомәдениттану, тарих, т.б. саладағы антропонимдер мен топонимдерге қатысты реалияларды халықаралық өлшемге сай етіп, қайта аударып шығудың - қиынныңқиыны. Мұндай реалия аудармасын толыққанды түсіну үшін қытай тілінің заңдылығын шетелдің қай дыбысын қалай қолданатынын білу керек. Шамалап, мөлшерлеп, жобалап аудару аударманы сәтті еңбек етіп шығармайды. Алайда бұған аударматануда ерекше көңіл бөліп тоқталуына себеп болатын жағдайлар баршылық. Ол біріншіден, бір ұлттың өмір салты екінші ұлтта айнымай қайталануы мүмкін емес; екіншіден, ол сөз контексте дара болып тұруы мүмкін; үшіншіден, ол сөздеерекше бір стильдік бояудың болуы міндетті емес. Осыдан барып ұлттық реалияны бейнелейтін сөздерді келесі бір тілде жеткізудің өзіндік шарттары, өзіне тән тәсілдерінің болуы - заңды құбылыс.

С. Влахов пен С.Флорин "Непервидимое в переводе" кітабында реалияны аударудың екі шарттылығын, кей жағдайда аударылмайтындығын, әдеттегідей контекстік аударма тәсілмен берілмейтіндігін дәлелдейді. Алайда А.В. Федоров “басқа тілге аударылмайтын ешқандай сөз болмайды” деп сөздік қатынас жағынан сипаттама жасалатынын, аударылатынын ескертеді [4, 1426.].

Реалийдің екі түрі бар: кәдімгі реалий, баламасыз лексика арқылы берілетін ұлттық лингвомәдени бірліктер және ассоциативтік реалий. Ассоциативтік реалийдің пайда болуы сөздің семантикалық құрылымында ерекше ұлттық компоненттің болуымен байланысты. Бұл ұлттық ерекше семалар сөздің лексикалық мағынасының құрамына кіреді. Сөздің лексикалық мағынасының құрамы денотат, сигнификат және коннотаттан тұрады. Сөздің бойындағы ұлттық нақышты көрсететін компонент немесе сема денотат деңгейінде де, коннотат деңгейінде де көрінеді. Коннотаттық мағынаны құраушы бөліктер бағалауыштық, ассоциативті-бейнелеуіштік, 
эмотивті және функциональды - стилистикалық сипатта болады. Аудару үдерісінде аудармашы аудару реалийдің заттық мағынасын (семантикасын) жеткізгенде оның тек сол ұлтқа тиесілі айшық-өрнектерін, ұлттық-тарихи ерекшелігін бере білу қажет.

Л.С. Бархударов баламасыз жеткізу тәсілдерін арнайы қарастыра келе, оның аударма үрдісінде бес түрлі жолмен көрініс табатындығын айтады. Олар: транслитерация және транскрипция; сөзбе-сөз аудару, яғни калька тәсілі; сипаттамалы аударма; баламалы аударма; трансформация [5, с.176]. А.К.Абишева көптеген зерттеушілердің практикасында кездесетін, ерекше семантикалық құрылымдағы, яғни ұлттық нақыштағы семантикалық компоненттері бар сөздерді берудегі негізгі тәсіл ретінде қолданылатын мынадай аударма түрлерін көрсетеді: транскрипция (транслитерация); ұқсату; лакунаны компенсациялау; сипаттамалы аударма; калька; тек-түрлік ауыстыру; функционалды сәйкестік; аудармалық түсіндірме [6, 154 б.].

Реалия сөздердің бір тілден екінші тілге аударғанда аударма мағынасының тура, дәл шықпайтыны бәрімізге белгілі құбылыс. Десек те аудармашылар, ғалымдар оларды аударуда бір тілден екінші тілге жеткізудің амал-тәсілдерін, жолдарын таба білген.Р.Сәрсенбаев мақаласында реалия сөздердің аудару жолының үш түрлі тәсілін ұсынса, А.В.Федоров көпке танымал оқулығында қосымша төртінші тәсілді қосады. Енді сол тәсілдерге тоқталсақ:

1.Транслитерациялау немесе транскрипциялау әдісі. Бұл әдіс бойынша реалия сөздер тілдің артикуляциялық ережеге сәйкес аударма тілдің фонетикалық жазу құралдарының көмегімен басқа тілге сол қалпында енеді. Мысалы, қазақ тіліндегі қылыз, құрm, ауыл, айналайын т.б. сөздер қытай тіліне графикалық мүмкіндіктерді ескере отырып жеткізіледі. Транслитерациялау немесе транскрипциялау әдісі негізінен адамның аты-жөнін, географиялық атауларды, мерзімді басылымдарды, фольклорлық шығарма кейіпкерлерінің, ұлттық-мәдени болмыстың аттарын т.б.аударуда кеңінен қолданылады [7, с.78].

2.Реалия сөздердің өзіндік ерекшелігін сақтап, аударылып отырған тілгеұғымды жеткізудің бір жолы -аударма ережесін пайдаланып, жаңа сөз жасау немесе сөз тіркесін жасау. Әрине, бұл түпнұсқадағы ұлттық бояуы қанық сөздерді аударма тілге жеткізудің өнімді тәсілі емес. Десек те, кейбір реалиялардың жаңа баламасын жасауға тура келеді.

3.Реалия сөздерге ана тілінен мағына және қызметі жағынан сай, дәл келмесе де, ұқсас мағына беретін балама табу.

4.Гипонимиялық әдіс (гипо-“под”, нимос-“название, атау”) әдіс немесе жуықтап, жинақтап аудару түрі болып табылады [8, 123б.].

Мақаладабіріншіден, қытай халқының жаңа жылына қатысты реалияларды аударуда көбінесе аударманың сипаттау және транскрипциялау әдістері қолданылады.

Екіншіден, транскрипция әдісі шет тіліндегі реалияны қысқа және жинақы түрде атауға мүмкіндік береді, тек сипаттау әдісі аудармада оның мағынасын егжей-тегжейлі және түсінікті түрде түсіндіруге көмектеседі.

Үшіншіден, реалия аудармасындағы қиындықтарда қытай мәдениетінен терең хабары болу аудармадағы қиындықтың дұрыс шешуге көмектесетінін және қытай тілі реалияларының нақышын сақтауға болатынын да ұмытпаған жөн.

Нәтижелер және талқылау.Қазіргі заманғы зерттеушілер ұсынған реалия аударудың негізгі тәсілдері транскрипциялау, калькалау әдісі- бастапқы бірліктің формасы немесе функциясының элементтерін сақтау қажет болған жағдайларда қолданылады. Мысалы:географиялық атауларды, тарихи-мәдени оқиғалар мен объектілерді, атақ пен даңқты, оқу орындарын, мемлекеттік мекемелерді, мұражайларды, терминдерді және т. б. беру үшін де қажет. Кейбір жағдайларда калькалау әдісіекітілдің типологиялық сипаттамасына байланысты бастапқы бірлікті жасыру процесінесүйенеді [7, с.98] сипаттама беру, шамалап аудару, функционалдық аналогы, сондай-ақ біріктірілген әдіс (транскрипция және калька, транскрипция және түсініктеме, калька және түсініктеме) $[9$, с.81].

Аударма тәсілдері мен нұсқалары арасындағы реалияны аудару тәсіліне таңдау жасау аударма тіліндегі аудармашылық сәйкестіктің тұрақтылығына байланысты және аударманың мақсатымен, сөйлеу ахуалының мәнмәтінімен, сондай-ақ аудармашының құзыреттілігімен анықталады. Зерттеушілердің тәжірибесі көрсеткендей, осы әдістердің ең тиімдісі аударма транскрипциясы мен сипаттау әдісі деп санауға болады. Бұл реалияны аударудың өзіндік “түпкілікті” нұсқалары, оны әртүрлі мәдениеттерді тасымалдаушылардың қабылдау ерекшеліктерінен көруге болады.

Сипаттау тәсілі реалияларды аударудағы жиі қолданылатынын көруге болады. Ал сөздің фонетикалық қабығын көшіруге мүмкіндік беретін транскрипция әдісі тұрақты әдіске айналады, алайда бұл тіл меңгермеген оқырмандарға кейде түсініксіз болып та көрінеді.Бұл әдісте бастапқы 
бірліктің мәнін сипаттау тұрақты сөздік сәйкестігі болмаған жағдайда немесе бастапқы және аудармалы тілдерде тиісті бірліктердің мағыналық функциялары сәйкес келмеген жағдайда қолданылады.

Қытай тіліндегі жаңа жыл мерекесіне қатысты реалияларды егжей-тегжейлі қарау және нақты мәнмәтін шеңберінде неғұрлым дұрыс және тиімді аударма нұсқасын ұсыну маңызды болып табылады. Қытай мерекелерінің бастысы - “Жаңа жыл”. Барлық қытайлықтардың сүйікті, дәстүрлі мерекесі Көктем мерекесі - чунщзиені (сөзбе сөз: “көктем мереке”) айтуға болады. Таратып айтар болсақ, жаңа жылдық реалияларды шартты түрде бірнеше топқа бөлуге болады, төменде олардың бірнешеуіне тоқталдық. Әдетте, қытайлықтар Жаңа жыл мерекесін шығыс, ай немесе (ауыл шаруашылығы) күнтізбесі бойынша атап өтеді. Сәйкесінше, көптеген жаңа жылға қатысты реалиялар уақыт есептеу жүйесінің ерекшеліктерімен байланысты. Мысалы: 除夕-chuхі (сөзбесөз: “өтпелі, соңғы кеш”) - ай күнтізбесі бойынша шығыс жылының соңғы күнінің кеші; 元旦yuandan (сөзбе-сөз: “бірінші күн”) -Жаңа жылдың бірінші күні; 正月初一 zhengyuechuyi (сөзбесөз: “бірінші ай таза ай”) - Жаңа жылдың бірінші айы және т.б .;

Келесі реалиялар адамдардың мереке күндеріндегі қызметіне, жұмысына байланысты. Мысалы: 贴倒福-tiedaofu (“бақыт» иероглифін жоғарыдан төмен қарай жабыстыру) қытайлықтар бақытты үйге келтіру үшін осындай иероглифті жазбаларды жабыстырады. Тағы бір мысал:春运 chunyun (сөзбе-сөз: “көктемгі көш”) - Қытай жаңа жылы қарсаңында орын алған аласапыран (аймақтар мен тұтастай ел аумағындағы қозғалыс), билет сатып алу, ұшақтар мен пойыздарда бос орындардың болмауы және т.б. қиыншылық туғызатын көлік және жолаушылардың жол қатынасын білдіреді.

Көптеген реалиялардың мәдени коннотациялары жаңа жылдық атрибуттармен байланысты көп ғасырлық тарихқа ие және мерекелік салттар мен дәстүрлер негізінде пайда болған. Мысалы: 压岁钱yasuiqian (жыл бойы ақша күту) - Қытайда жаңа жыл мерекесінде балалар мен бойдақ қыздарға сыйлық ретінде сыйлайтын қызыл конверттегі ақша; 春天 chunlian (көктемді біріктіру,春 节对联толық мағынасы “жаңа жылдық жұп жазулар” қос жолдан тұратын тіркес, қызыл қағаздың қос жолақтары, олар көктем мерекесі кезінде үйінен зұлым рухтарды үркітеді деген мақсатпен есік жақтауларына ілінген.

Жаңа енген жылдың астрологиялық белгілерімен байланысты реалиялар өте қызық. Мысалы, 2016 жылдың атақты талисманы - маймыл Канкан (康康) болды, (сөзбе сөз: «денсаулық») денсаулық және ұзақ өмір тілегі. Оның алдындағы жылдың талисманы (2015 жыл) - қозы, 阳阳Yanyan атауынан (“күн сәулесі”) яғни, “қой” мен “күн” сөздерінің омофондың ұқсастығы негізде жасалған. Сондай-ақ, Жаңа жыл сауда маркаларында бейнеленген年娃 Ниенва қуыршағы (ұл куыршақ) және Chunny 春抳 қуыршағы (қыз қуыршақ) 2016 жылдың жүлдесіне айналды.

Шет тілінен аударма жасауда реалияның сөздіктерде тұрақты аудармасы мен баламалары кездеспейді. Қытай тіліндегі жаңа жыл мерекесіне қатысты реалияларды аудару барысында, көбінесе, транскрипция әдісі арқылы орыс тіліне аударылады және түр кеңінен қолданылады, мысалы:

过去, 中国人在过年的时候, 总喜欢买几张喜气洋洋的年画。

Қытай Жаңһа жылды тойлау кезінде қытайлықтар үнемі бақыыт әкеледі дегенбірнеше ниенхуа жаңңажылдық (арзан) суреттерді сатып алатын.

Транскрипция әдісін қолданғанда инофондарға ниенхуа дегеннің мағынасы неекенін және аудармада тек сипаттау әдісін пайдалану берілген мағынаны түсінікті етеді.

Тағы бір мысал: 新年最高兴的是孩子, 因为他们得到很多压假钱.

Жаңңа жыл балалар үшін қуанышты мереке, себебі олар қъызыл конвертте ақщаның көп болатынын біледі.

压假钱 реалиясын аудару кезінде сипаттау әдісін пайдалану қажет, өйткені сипаттау осы реалияның мағынасын толық ашып көрсете алады [10, 页.232]. 
Тағы бір мысал: 发布会上, 同时举行了中国邮政集团2016《拜年》主题邮票、《中华春节吉 祥物全球发布》纪念封发行仪式.

Пресс-конферениия барысында Қытай пошта қызметінің 2016 жылвы жаңза жылдық мөрінің маркасын таныстыру рәсімімен қ̧оса, «әлемге әйгілі Қытай көктемінің бойтұмары” атты естелік мөрді тапсыру расімі өтті.

年娃、春妮，被选为春节吉祥物，充满民族特色，又洋溢浓浓年味儿[11, 页.198].

Көктем мерекесінің бойтұмары болып таңдалған Ниенва мен Чунни ұлттық нақышпен жаңа жылдық мейрамға сай жасалды.年娃және春妮реалияларының аудармасын сөздіктерден табу мүмкін емес, өйткені біріншіден бұлар жалқы есімдер, екіншіден - неологизмдер.

Қорытынды. Реалия сөздер қытай тілі лексикологиясындағы үлкен бір категория екенін пайымдай келе, онда табиғи түрде, басқа ғылымдар сияқты оның да теориясы болатындығына, сонымен бірге оның практикалық жұмысының да аса маңызды екеніне мән бермей қоюға болмайтынын анықтадық. Реалиялар - қай-қай тілдің болса да тіл байлығының көрсеткіші, сөз қорының алтын сандық, асыл қазынысы. Сонымен бірге тілді алдағы кезде бұдан да бай, әрі оралымды ету үшін оның шексіз мүмкіншіліктерін барынша іздестіріп, кәдеге жарата білуіміз қажет. Күнделікті тәжірибеде реалияны қолдану аясын орнықтырып, саралап, бір ізге келтіру қажет. Қытай тіліндегі реалия сөздер арқылы сөздік қорды байытуға болады. Бұл үшін ең алдымен әрбір реалия сөздердің аударма барысындағы айырмашылықтарын жіті түсіне біліп, оны жанжақтылы қолдана білу керек. Реалия сөздердің қызметі, әсіресе, жазушылардың көркем шығарма жазу барысында ерекше рөлі болады. Реалия сөздердің сөздік қатардағы сөздермен бір-бірімен қаншалық айырмашылығы бар екенін және олардың әрқайсысын қалай қолдану қажет екенін толық білмегенде, түпнұсқаның мағынасын дәл бейнелеу қиынға соғатынын байқадық. Себебі, ол жоқ дегенде шығарманың көркемдігіне нұқсан келтіреді. Негізгі ой айқын бейнеленбей, бұлдырлап, нобайы ғана түсіндіріледі. Жазушының шеберлігі үшін бұл үлкен сын болады. Сондықтан жазушы немес ақын ең алдымен қытай тіліндегі реалия сөздерді дұрыс түсіне алуы және олардың бір-бірінен айырмашылықтарын жақсы мөлшерлеп, дәл қолдануға баса назар аударлуы тиіс.

Пайдаланылван ддебиеттер тізімі:

1) Федоров А.В. Основы общей теории перевода. -Москва: Высшая школа, 1983. - 400 с. кiman

2) Латышев Л.К. Перевод проблемь теории, практики и методики преподавания/Л.К.Латышев. -М.: Просвещение,1988. - 160с. - кітап

3) Виноградов В.С. Введение в переводоведение (общие и лексические вопросы)/В.С. Виноградов. -М.:Института общего среднего образования РАО, 2001. -231с.- журнал кiman

4) Тарақ̆ов Ә. Аударма әлемі/ Ә.Тарақ̧ов. -Алматы: Қазақ университеті, 2011ж. -330 б. -

5) Бархударов Л.С. Язык и перевод. Вопросы общей и частной теории перевода/Л.С. Бархударов. - Москва: Международные отношения, 1975. -240 c.-кітап

6) Абитева К.М. Основы теории и практика перевода/ К.М.Абишева. - Астана: Университет “Туран-Астана", 2008. -272 c. - кітап

7) Жақыппов Ж.А. Аударматануды аңдату/ Ж.А.Жақыпов. - Астана: InпоPRESS, 2004. -191 6.- кiman.

8) Казакова Т.А. Практические основы перевода/ Т.А.Казакова. - СПб.: Союз, 2002. -320с.кiman

9) Виноградов В.С. Лексические вопросы перевода художественной прозы. -М.: Издательство Московского университета, 1978. -172c.-кітап

10) 现代汉语大词典：上册。一上海：上海辞书出版社, 2012 年。-1500 页. - сөздi

11) 现代汉语词典。-上海: 华东师范大学出版社, 2004年. -2500 页. - co3di 